\title{
2-2016
}

\section{Predicting Genocide and Mass Atrocities}

Ernesto Verdeja

University of Notre Dame

Follow this and additional works at: https://digitalcommons.usf.edu/gsp

\section{Recommended Citation}

Verdeja, Ernesto (2016) "Predicting Genocide and Mass Atrocities," Genocide Studies and Prevention: An International Journal: Vol. 9: Iss. 3: 13-32.

DOI:

http://dx.doi.org/10.5038/1911-9933.9.3.1314

Available at: https://digitalcommons.usf.edu/gsp/vol9/iss3/5

This is brought to you for free and open access by the Open Access Journals at Digital Commons @ University of South Florida. It has been accepted for inclusion in Genocide Studies and Prevention: An International Journal by an authorized editor of Digital Commons @ University of South Florida. For more information, please contact digitalcommons@usf.edu. 


\section{Predicting Genocide and Mass Atrocities}

\section{Acknowledgements}

Special thanks to Isabelle Arradon, Andrew Basso, Emmanuel Bombande, Anna de Courcy Wheeler, Benjamin Goldsmith, Gillian Kitley, Christopher Mauriello, Adam Muller, Alessandra Necamp, Scott Straus, Christopher Tuckwood and Stephenie Young for their comments and discussions on these issues. Brittany Ebeling and Jennifer Flanagan provided valuable research assistance. Earlier versions of this paper were presented in 2014 at the Center for Holocaust and Genocide Studies at Salem State University and in 2015 at the International Association of Genocide Scholars conference in Yerevan, Armenia. 


\title{
Predicting Genocide and Mass Atrocities
}

\author{
Ernesto Verdeja \\ University of Notre Dame \\ Notre Dame, IN, USA
}

\begin{abstract}
This article examines several current risk assessment and early warning models to predict genocide and mass atrocities. Risk assessment (RA) concerns a country's long-term structural conditions (regime type, state-led discrimination, etc.) that determine overall risk for atrocities. Early warning (EW) focuses on short/midterm dynamics that can serve as triggers. The article evaluates contemporary RA and EW forecast modeling, and asks: How well can we predict mass atrocities and genocide? What are the strengths and limitations to current predictive modeling? Part I examines several quantitative (statistical) RA models and identifies several strengths and limitations in current research. Part II investigates a number of $E W$ approaches, and also discusses their strengths and areas for further development. The article notes the impressive advances that have been made in the past fifteen years in $R A$ and $E W$, but also counsels realistic expectations the possibilities of forecasting.
\end{abstract}

Keywords: genocide, early warning, risk assessment, prediction, forecasting

Since the Rwandan and Bosnian genocides of the 1990s, policymakers have placed a premium on predicting and halting mass killings and genocide. Governments, human rights nongovernmental organizations (NGOs) and the United Nations (UN), among others, have developed a host of preventive policy architectures, many influenced by the 'responsibility to protect' principle articulated in 2001 and later adopted by the UN. ${ }^{1}$ These international concerns over mass killing have also spurred increased attention to developing sophisticated models of prediction-how accurately can genocide and mass killings be predicted? What are the strengths and limitations of predictive modeling, and what still remains to be done?

This article examines the state of genocide and mass atrocity prediction, also known as forecasting. ${ }^{2}$ A predictive model is part of a broader alert system that, as formulated by Lawrence Woocher, includes a) periodic global risk assessments that produce useful country watch lists; b) sustained, detailed monitoring and analysis of high risk situations; and, c) a mechanism for communicating warnings to end users, such as policymakers. ${ }^{3}$ This article focuses on the first two elements of Woocher's list, with the understanding that forecasting is only one, albeit important, element in stopping mass violence more generally; clearly, the findings of researchers need to be useful and intelligible to policymakers and communicated in a regular and timely manner, and political will needs to be mobilized and sustained. Indeed, the challenge of generating political will may very well be the most important dimension of the preventive architecture, and it has certainly received the most attention from scholars, activists and political leaders. ${ }^{4}$ This article, however, has a more circumscribed focus. It assesses the kinds of models currently in place and identifies a number of strengths and limitations to predicting complex phenomena like genocide and largescale killing. It also raises some broader epistemological questions about prediction and counsels caution on expecting too great accuracy or specificity.

Barbara Harff and Birger Heldt argue that prediction models tend to fall into one of two categories-risk assessment (RA) or early warning (EW). Although the terms are often used

\footnotetext{
${ }^{1}$ Bellamy, Alex. 2009. The Responsibility to Protect. Cambridge: Polity.

${ }^{2}$ There is also a large prediction literature devoted to other kinds of risk, including environmental hazards and famine, that has informed mass atrocity forecasting; Secretary General of the United Nations. 2006. Early Warning Systems. New York: United Nations.

${ }^{3}$ Woocher, Lawrence. 2011. "Is a Public Warning System Necessary?" United States Holocaust Memorial Museum. Available from: www.ushmm.org/m/pdfs/20111021-woocher-early-warning.pdf (accessed December 23 2015).

${ }^{4}$ Meyer, Christoph O., Florian Otto, John Brante, Chiara de Franco. 2010. "Recasting the Warning-Response Problem: Persuasion and Preventive Policy." International Studies Review Vol. 12, 556-578; Lupel, Adam and Ernesto Verdeja. 2013. "Developing the Political Will to Respond." In Responding to Genocide: The Politics of International Action. Edited by Adam Lupel and Ernesto Verdeja. Boulder, CO: Lynne Rienner, 241-257; Weiss, Thomas G. 2012. What's Wrong with the United Nations and How to Fix It. London: Polity.
} 
synonymously, they in fact have different objects of analysis and purposes. ${ }^{5}$ Risk assessment focuses on the general structural elements of a society that affect its likelihood of experiencing significant human rights violations. These elements may include, inter alia, political regime type (e.g. autocratic, democratic), prior history of political instability, degree of integration into the global economy, and levels of state-led discrimination. Risk assessments measure each of these and other factors in a particular country and generate a score of high, medium or low risk for violence in the future. These models are largely static: the values of the relevant factors do not tend to fluctuate rapidly in short periods of time - for instance, regime type is hard to change-and they draw on data from past periods to predict the future. Risk assessments are useful for providing an overall picture of the state of affairs, but do not predict if - much less when-genocidal violence or instability will take place.

Early warning focuses on the mid- and short-term factors that make violence likely. This includes attempts to identify the escalation of instability and whether it may tip into largescale, sustained violence. Naturally, this requires greater attention to dynamic elements such as widening cleavages among political elites, changes in the military capacity of oppositional forces, highly contested upcoming elections, and the expansion of security forces. Early warning models also often track other factors that may arrest or deescalate volatile dynamics, such as the presence and strengthening of peacekeeping forces to reinforce stability, temporary cease-fires, and other short or mid-term policies that aim to create a space for political negotiation and eventual conflict termination or transformation. In essence, early warning focuses on processes of violence onset, escalation, sustainment, and abeyance, rather than the long-term structural conditions that indicate general risk levels of instability and violence.

While early warnings should be "timely, accurate, valid, reliable and verifiable," it would be misguided to expect that there can be highly precise predictions of when and where violence will occur. ${ }^{6}$ That would be too high a standard to espouse, and assumes a level of scientific accuracy that is unattainable. Early warning will be more useful if the focus is not on perfect forecasting, but instead on providing policymakers with timely and sufficiently accurate information about dynamics of escalation that can assist prevention or intervention. Early warning does not need to be perfect-it never will be-but it should be suitably concrete that it can inform policy.

The following pages first discuss risk assessments and then move on to early warning, highlighting their respective strengths and limitations. The RA models discussed below are mostly produced by academic researchers using a variety of statistical techniques, but are meant for policy purposes. I focus on these models because they are among the best in the field and are transparent about the methods they employ, which allows readers to evaluate how they arrive at their forecasts. For models that integrate risk assessment and early warning (typical of governments, international organizations, and nongovernmental organizations), I leave the discussion for the early warning section.

\section{Risk Assessment}

Before moving on to the various risk assessment models, a few words on prediction and causation are in order. Risk assessments are predictive models, and not necessarily causal models. This has certain implications for how they frame their analyses. A causal model focuses on explaining the processes and mechanisms by which some factors cause some outcome, such as genocide. This requires specifying a chain of causality and ruling out competing causal factors, processes and theories. Causal theories include only those factors that can be shown to have a causal impact on the outcome. Predictive theories, however, are less concerned with explaining causal relations and

\footnotetext{
${ }^{5}$ Harff, Barbara. 2013. "Detection: The History and Politics of Early Warning." In Responding to Genocide: The Politics of International Action. Edited by Adam Lupel and Ernesto Verdeja. Boulder, CO: Lynne Rienner, 85-110; Heldt, Birger. 2009. "Risks, Early Warning and Management of Atrocities and Genocide: Lessons from Statistical Research." Politorbis Vol. 2, No. 47, 65-70.

${ }^{6}$ Schmeidal, Susanne. 2002. "Conflict Early Warning and Prevention: Toward a Coherent Terminology." In Early Warning and Conflict Management in the Horn of Africa. Edited by Ciru Mwaura and Susanne Schmeidal. Lawrenceville, NJ: Red Sea Press, 81; Clarke, John. 2005. "Early Warning Analysis for Humanitarian Preparedness and Conflict Prevention." Civil Wars Vol. 7, No. 1, 71-91.
} 
more with forecasting the probability of some event. There may be some factors that are highly correlated with the event and are thus useful for estimating outcome probabilities, but the factors do not have an obvious causal relationship to the outcome.

The two types of enterprises-prediction and causal analysis-do overlap. Naturally, if a researcher knows the specific causes of some event such as genocide onset and has sufficient and high quality information for all of the causal factors in her model, she can in principle predict the event's likelihood with some degree of accuracy. But of course, in "real time" such information is often imprecise, contradictory, or otherwise not fully available. And in any case, there are so many complex relations between structural and contingent causal factors that rough probabilities are the most that can be expected. Our theories on the causes of genocide are developed posthoc, and rely on a significant amount of historical reconstruction-through interviews, archival research, forensic anthropological investigations, and the like. They seek to explain how (and why) genocide occurs. Prediction, however, is less concerned with explanation, and thus prediction models such as risk assessments pragmatically use those variables that are highly correlated with event outcome, regardless of whether those variables have causal impact or explanatory value. As will be evident below, these predictive models draw heavily on the causal theory literature, but may also use variables that have little causal connection to genocide and mass atrocities but are nevertheless correlated.

The attempt to predict systematically large-scale violent phenomena has its modern origins in post-Cold War efforts to model the likelihood of nuclear war between the United States and the Soviet Union. Think tanks such as RAND, funded by the US government, developed risk assessments that took into account the general political and economic stability and military capacity of each superpower, as well as their ability to control their respective allies and satellite states. Similar models were developed to assess the likelihood of war in the European theatre between NATO and Warsaw forces as well as the relative vulnerability and resilience of governments across the so-called Third World. Many of these models promised a degree of accuracy and predictability that could not be met, leading to significant skepticism about risk assessments among high-level US policymakers.

The Rwandan and Bosnian genocides generated a renewed interest in risk assessments to assist in policy planning. In 1994, the US government established a research group to investigate and predict the likelihood of severe instability around the globe. Known as the Political Instability Task Force (PITF; originally the State Failure Task Force), the group has examined a variety of state failure scenarios, including rapid regime change, civil wars, and genocide and mass killing. The PITF is the first large-scale statistical modeling project employing large datasets to forecast instability. It has provided a risk assessment of all countries around the globe by examining the conditions that precede the onset of major instability. ${ }^{8}$

Jack Goldstone and his colleagues use PITF data for a parsimonious model that predicts the onset of political instability, which they define as revolutionary and ethnic wars (at least 1,000 total deaths and 100 deaths per year), adverse regime changes (sudden loss of authority by the state, or replacement by a non-democratic government), and mass atrocities (including genocide). ${ }^{9}$ The authors experimented with a host of variables from the genocide and instability literature, and settled on four: regime type, infant mortality rate (logged); extent of conflict in neighboring countries; and extent of state-led discrimination. The authors tested the model on countries worldwide from 1955 to 2003 and found the model could predict (with a two-year lead time) the

\footnotetext{
${ }^{7}$ For the hubris of early thinking on these issues, see Edwards, Paul N. 1997. The Closed World: Computers and the Politics of Discourse in Cold War America. Cambridge: MIT Press.

${ }^{8}$ The PITF data are archived at George Mason University, available at www.globalpolicy.gmu.edu/political-instabilitytask-force/political-instability-task-force-home/ (accessed 10 June 2015). The Center for Systemic Peace continues to produce annual watch lists based on the PITF's work, and is available at www.systemicpeace.org (accessed 10 June 2015). Also see the work of the Center for International Development and Conflict Management at the University of Maryland, www.cidcm.umd.edu/ (accessed 10 June 2015).

${ }^{9}$ Goldstone, Jack, Robert H. Bates, David L. Epstein, Tedd Robert Gurr, Michael B. Lustick, Monty G. Marshall, Jay Ulfelder and Mark Woodward. 2010. "A Global Model for Forecasting Political Instability." American Journal of Political Science Vol. 54, No. 1, 190-208.
} 
onset of political instability with over 80 percent accuracy. One of the major conclusions is that political institutions, rather than economic or demographic conditions or geography, serve as the most important predictors of political instability.

The Goldstone et. al. model focuses on a very capacious dependent variable: political instability, which includes but is not limited to genocide and mass atrocities. Barbara Harff, also working with PITF, has developed the best-known predictive model for genocide. In 2003, Harff published a model that sought to predict genocide and politicide, which she defines together as "the promotion, execution, and/or implied consent of sustained policies by governing elites or their agents-or, in the case of civil war, either of the contending authorities-that are intended to destroy, in whole or part, a communal, political, or politicized ethnic group" ${ }^{10}$ The model is predictive for countries already experiencing state failure, essentially civil wars or "reversals" in democracy. She employs six causal factors, which when combined predicted geno/politicide onset with 74 percent accuracy, and non-onset with 73 percent accuracy. The study covers the years 1955 to 2001. This is essentially a conditional model: it selects cases for analysis based on the prior condition of state failure (which may include civil war or democracy reversal). Harff respecificed the model in the following years, and the most recent version uses seven causal factors. ${ }^{11}$ These include 1) a history of prior geno/politicide since 1955;2) ethnic character of the ruling elite (whether the governing elite represents a minority group); 3 ) exclusionary elite ideology (a ruling ideology that sanctions persecution or elimination of other groups); 4) regime type (autocracy or democracy, with autocracies more highly correlated with geno/politicide); 5) trade openness (sum of exports and imports as percentage of GDP, with trade openness inversely correlated with geno/politicide); 6) state-led discrimination (systematic limitation of economic or political rights); and, 7) instability risks (major instabilities such as civil war, revolution or rapid change in regime). Each of these factors is weighted, with a higher score indicating higher risk. Countries with high cumulative scores are classified as having high risks of geno/politicide. ${ }^{12}$ The Harff model has served as the touchstone for most contemporary statistical forecasting models and was cited by the 2008 US Genocide Prevention Taskforce as a central component for developing genocide prevention policy, and is reportedly used by the US government's Atrocities Prevention Board. ${ }^{13}$

Nicholas Rost has also developed and tested a variety of prediction models. He attempts to predict the onset of three violent phenomena: "mass killing" (the intentional killing by a government of at least 1,000 civilians), Harff's geno/politicide, and democide, or "death by government."14 Though there is significant overlap in these forms of violence, they are somewhat different and seem to have different predictive factors. For instance, according to Rost, a country's trade dependence is correlated with democide, but not with genocide or mass killing. Furthermore, economic discrimination against an ethnic or communal group prior to armed conflict does not predict genocide, though political threats such as riots and "high-level" assassinations are in fact correlated. The variables with the strongest predictive power for the onset of genocide include regime type, interstate war, assassinations, prior limitations of rights, militarization, population displacement, and perhaps most surprisingly, presence of a peacekeeping force. Peacekeeping may be highly correlated for the simple reason that peacekeeping forces are only sent to countries already at risk of mass violence. ${ }^{15}$ He finds that overall, the onset of democide is significantly

\footnotetext{
${ }^{10}$ Harff, Barbara. 2003. “No Lessons Learned from the Holocaust? Assessing Risks of Genocide and Political Mass Murder since 1955." American Political Science Review Vol. 97, No.1, 58.

${ }^{11}$ Harff, "Detection: The History and Politics of Early Warning," 85-110.

${ }^{12}$ Also see Chad Hazlett's interesting alternative model based on Harff, which drops her predictive factors of "prior genocides" and the "ethnic character of elites" in favor of the "strategic motivations of regimes". Hazlett, "New Lessons Learned", 2011.

${ }^{13}$ Albright, Madeleine K. and William S. Cohen. 2008. Preventing Genocide: A Blueprint for U.S. Policymakers. Washington, D.C.: United States Holocaust Memorial Museum, 25; Norris, John and Annie Malknecht. 2013. Atrocities Prevention Board: Background, Performance, and Option. Washington, D.C.: Center for American Progress.

${ }^{14}$ Rost, Nicolas. 2013. "Will It Happen Again? On the Possibility of Forecasting the Risk of Genocide." Journal of Genocide Research Vol. 15, No. 1, 42, 52-53.

${ }^{15}$ The relation between peacekeeping and genocide and armed conflict is complex, but see Melander, Erik. 2009. "Selected To Go Where Murderers Lurk? The Preventive Effect of Peacekeeping on Mass Killings of Civilians." Conflict Management
} 
harder to predict that genocide or mass killing, and notes a high rate of false alarms in the various models he examines.

Benjamin Goldsmith, director of the Australian Atrocity Forecasting Project, and his colleagues have produced a statistical forecasting model that builds on the work of Harff and others. ${ }^{16}$ Their model is essentially two-stage: first, it predicts a country's probability of violent instability, which may include civil wars or coups. The second stage employs that probability as well as other factors to predict the specific likelihood of genocide onset three to five years in the future (they use Harff's definition of genocide). The authors tested a wide range of variables, but the most powerful predictors for genocide onset included (in addition to instability) prior genocide, "human defense burden" (proportion of a population in the regular military over a given year), "executive constraints" (extent of checks and balances on autonomy of the executive), state-led discrimination, infant mortality rate, and number of neighboring state conflicts. ${ }^{17}$ This is not strictly a conditional model; all countries are evaluated, and there is no prior condition of violent instability that has to be met for inclusion in the second stage of analysis. Although violent instability is an important predictor of genocide, the authors avoided using this as the "gate" for inclusion in second stage. The benefit of a non-conditional model is that it avoids the risk of excluding some countries that do not meet a particular threshold but otherwise may experience genocide in the future. The authors find that their model predicts 82 percent of genocide onsets correctly and 79 percent of non-onset years correctly, which is an impressive outcome. One interesting finding is that certain economic factors that are highly correlated with civil war ${ }^{18}$ and general violent instability such as poverty, unemployment rate, unemployment change, proportion of men in the labor force, and so forth, are not good predictors of genocide. Economic factors are important when mediated by other political factors, such as type of political regime, but not on their own. Given that most post-World War II genocides occur in the context of civil war, revolution or coups, this means that economic factors predict a wider range of violent phenomena than genocide as such.

Jay Ulfelder and the Early Warning Project (EWP) have sought to produce risk assessments of the potential for "state-led mass killings" (rather than only geno/politicide) annually for all countries. ${ }^{19}$ The EWP's approach is also nonconditional, and thus countries are not required to meet a certain instability threshold for inclusion. This approach combines an opinion pool and statistical modeling to produce assessments. The opinion pool collects country forecasts from a relatively large group of experts. ${ }^{20}$ The statistical component uses an "ensemble Bayesian" forecast that involves combining three statistical RA models and aggregating their predictions to generate one final probability score of mass killing per country per year. The models include 1) a combination of Harff's original 2003 model on geno/politicide and Goldstone et. al. on political instability;

and Peace Science Vol. 29, No. 4: pages 389-406; Fortna, Virginia Page. 2008. “Does Peacekeeping Keep Peace? International Intervention and the Duration of Peace After Civil War." International Studies Quarterly Vol. 48: pages 269-292.

${ }^{16}$ Butcher, Charles R., Benjamin E. Goldsmith, Dimitri Semenovich and Arcot Sowmya. 2013a. "Understanding and Forecasting Political Instability and Genocide for Early Warning." Sydney: Australian Government, Asia Pacific Centre for the Responsibility to Protect, The University of Sydney, The University of New South Wales. Available from: $w w w$. sydney.edu.au/arts/research/atrocity forecasting/downloads/docs/GenocidePolicyReportGlobalLowRes final120905.pdf (accessed 7 January 2015); the authors use the term "early warning" in their title in the way risk assessment is used here. Also see Butcher, Goldsmith, Semenovich and Sowmya 2013b.

${ }^{17}$ Butcher et al. "Understanding and Forecasting Political Instability", 15.

${ }^{18}$ Hegre, Håvard and Nicholas Sambanis. 2006. "Sensitivity Analysis of Empirical Results on Civil War Onsets." Journal of Conflict Resolution Vol. 50, No. 4, 508-535.

${ }^{19}$ Early Warning Project. 2015a. Available from: http://www.earlywarningproject.com (accessed 9 June 2015); also see Ulfelder, Jay. 2013. "A Multimodel Ensemble to Forecast Onsets of State-sponsored Mass Killing." American Political Science Association Annual Meeting. Available from: www.ssrn.com/abstract=2303048 (accessed 10 January 2015) and Early Warning Project. 2015d. "A New Statistical Approach to Assessing Risks of State-Led Mass Killing." Available from: http://www.earlywarningproject.com/2014/01/22/a-new-statistical-approach-to-assessing-risks-of-state-led-masskilling (accessed 9 June 2015), where many of the technical details are laid out. The EWP also runs an annual Wiki survey to assess the risk of mass killing, see Early Warning Project. 2015c. "Wiki Survey." Available from: http://www. earlywarningproject.com/2015/01/12/relative-risks-of-state-led-mass-killing-onset-in-2015-results-from-a-wiki-survey (accessed 9 June 2015). For frequently updated discussions of this work, see www.dartthrowingchimp.wordpress.com ${ }^{20}$ Early Warning Project. 2015b. “Expert Opinion Pool.” Available from: http://www.earlywarningproject.com/opinion pools (accessed 9 June 2015). 
2) an "elite threat" model for predicting civil wars and coups; and, 3) a "random forest" approach that employs the variables in the previous models as well as a few others. Ensemble forecasting avoids the pitfall of having to pick one "best" model when the researcher has little confidence for privileging one above the other since various models will each have particular strengths and limitations. The EWP's ensemble model does not use specific variables to predict mass killing but rather averages across models, so there is no set of main predictors as is the case with models discussed earlier. However, Ulfelder finds that overall an ensemble approach produces better forecasts than using one statistical model. ${ }^{21}$ Results are updated at www.earlywarningproject.com.

The Fund for Peace is a think tank that has produced an annual Fragile States Index for the past decade and currently covers 178 countries. The Fund also publishes a shorter watch list of highly fragile states based on the Index. Unlike most nongovernmental organizations involved in risk assessment, the Fund's sources, coding criteria and analytical model are publicly available, and the model has been refined over time following periodic peer review. It is among the more methodologically transparent and rigorous assessments developed by a policy think tank. The Index defines fragile states as those that have lost control of territory or monopoly of legitimate use of force (the classic Weberian definition of the state), the erosion of legitimate authority to make collective decisions, a failure to provide public services, or the inability to interact with other states as a "full member of the international community" (i.e., legal sovereignty is questioned). ${ }^{22}$ The analysis employs a framework called Conflict Assessment System Tool (CAST), which uses twelve general indicators to assess the degree of state fragility. The indicators fall broadly in three categories: social (demographic pressures, displaced persons, group grievances, human flight); economic (uneven economic development, poverty and economic decline); and political and military (state legitimacy, public services, human rights and rule of law, security apparatus, elite factionalization, external interventions). ${ }^{23}$ Unlike the examples discussed earlier, the Index does not produce systematic predictions for violence or instability onset in the future; rather, it provides assessments of current levels of state fragility. Like Goldstone et. al.'s model, the Index focuses on a much broader range of instability outcomes than mass violence and genocide, though in practice its country watch list overlaps extensively with other watch lists.

The RA models discussed above differ in various ways. Aside from employing a variety of different indicators and statistical methods, they also attempt to forecast somewhat different phenomena: political instability, state fragility, state-sponsored mass killings, democide, or politicide and genocide. Nevertheless, there is significant overlap in the countries that qualify as high risk in each model. Table 1 shows this by model, with the fifteen highest risk countries listed by descending risk score in each column. Note that although these countries are "ranked" by model, the rankings are not meant to reflect exact risk level differences between countries; rather they simply show comparative levels of risk. I exclude the Goldstone et. al. country list because it is older than the other lists presented here, so it is not as comparable. Rost is testing the efficacy of models and he does not generate a list of countries, so his findings are not included either.

What can we make of this? The table shows some consistency across models, even if specific country rankings differ (recall that EWP's is an ensemble model, so it includes the 2003 version of the Harff model). For instance, the Democratic Republic of the Congo and Somalia appear on all four lists, and Afghanistan, the Central African Republic, Guinea, Myanmar (Burma), Pakistan, Sudan and Syria are on three. A number of countries are on two lists: Cameroon, Chad, Ethiopia, Iraq, Nigeria, Rwanda, Sri Lanka, South Sudan and Zimbabwe. Of course, many other countries are ranked a bit lower and thus do not appear here, but show up consistently across models.

The differences across lists are a product of the specific outcome that is being measured (genocide onset, state fragility, etc.) and the various model specifications. Nevertheless, the bundling of high-risk countries across sub-Saharan Africa, the Middle East and south Asia suggests

\footnotetext{
${ }^{21}$ Ulfelder, "A Multimodel Ensemble to Forecast Onsets of State-sponsored Mass Killing," 15.

${ }^{22}$ Early Warning Project. 2015a.

${ }^{23}$ Haken, Nate, J. J. Messner, Krista Hendry, Patricia Taft, Kendall Lawrence, Laura Brisard, and Felipe Umaña. 2014. Failed State Index 2014: The Book. Washington, D.C.: Fund for Peace.
} 
Table 1. Highest-Risk Countries by Model

\begin{tabular}{|c|c|c|c|}
\hline $\begin{array}{c}\text { Harff } \\
\text { (genocide and } \\
\text { politicide) }\end{array}$ & $\begin{array}{l}\text { Butcher et. al. } \\
\text { (genocide and } \\
\text { politicide) }\end{array}$ & $\begin{array}{c}\text { EWP } \\
\text { (state-led mass } \\
\text { killing) }\end{array}$ & $\begin{array}{l}\text { Fragile States } \\
\text { Index }\end{array}$ \\
\hline Syria & $\begin{array}{c}\text { Central African } \\
\text { Republic }\end{array}$ & Myanmar & South Sudan \\
\hline Myanmar & D. R. Congo & Sudan & Somalia \\
\hline Sudan & Chad & $\begin{array}{c}\text { Central African } \\
\text { Republic }\end{array}$ & $\begin{array}{c}\text { Central African } \\
\text { Republic }\end{array}$ \\
\hline Pakistan & Somalia & Pakistan & D. R. Congo \\
\hline Ethiopia & Angola & South Sudan & Sudan \\
\hline Rwanda & Myanmar & Somalia & Chad \\
\hline Zimbabwe & Sri Lanka & D. R. Congo & Afghanistan \\
\hline China & Ecuador & Iraq & Yemen \\
\hline Iran & Burundi & Mali & Haiti \\
\hline D. R. Congo & Afghanistan & Guinea & Pakistan \\
\hline Somalia & Syria & Afghanistan & Zimbabwe \\
\hline Saudi Arabia & Guinea & Bangladesh & Guinea \\
\hline Sri Lanka & Cameroon & Nigeria & Iraq \\
\hline Nigeria & Uganda & Ethiopia & Cote d'Ivoire \\
\hline Cameroon & Libya & Rwanda & Syria \\
\hline
\end{tabular}

Source: Harff, “Detection: The History and Politics of Early Warning," 97: Table 4.1; Butcher et.al, "Understanding and Forecasting Political Instability," Table 1; Early Warning Project 2015e; Fund For Peace 2015b; On the Index, the first five countries are ranked "very high alert" and the following ten are ranked "high alert."

${ }^{1}$ Harff, "Detection: The History and Politics of Early Warning," 97: Table 4.1; Butcher et.al, "Understanding and Forecasting Political Instability," Table 1; Early Warning Project 2015e; Fund For Peace 2015b; On the Index, the first five countries are ranked "very high alert" and the following ten are ranked "high alert."

that many of the factors that predict one violent or disruptive outcome have some effects on others, though as we saw earlier there is variation in particular indicators and variables.

Another equally important pattern emerges, which concerns regional concentrations of risk. The models focus on country-year as the unit of analysis, but as Martin Shaw has argued, the causes of genocide and similar forms of violence cannot be explained solely by country-level analysis. In fact, there may be broader international and regional factors that exacerbate (or mitigate) risk and help determine regional concentrations of violence at given historical periods. ${ }^{24}$ The lists themselves suggest this when mapped. Below are two global "heat" maps, which reflect the Fragile States Index and EWP lists in Table 1. The maps below are taken from these sources.

In Map 1, high-risk countries are in dark red and low risk countries are in green. The map reveals a concentration of fragile states across Africa, the Middle East and south Asia, with generally moderate levels in Latin America and other parts of Asia.

${ }^{24}$ Shaw, Martin. 2013. Genocide and International Relations: Changing Patterns in the Transitions of the Late Modern World. Cambridge: Cambridge University Press. 


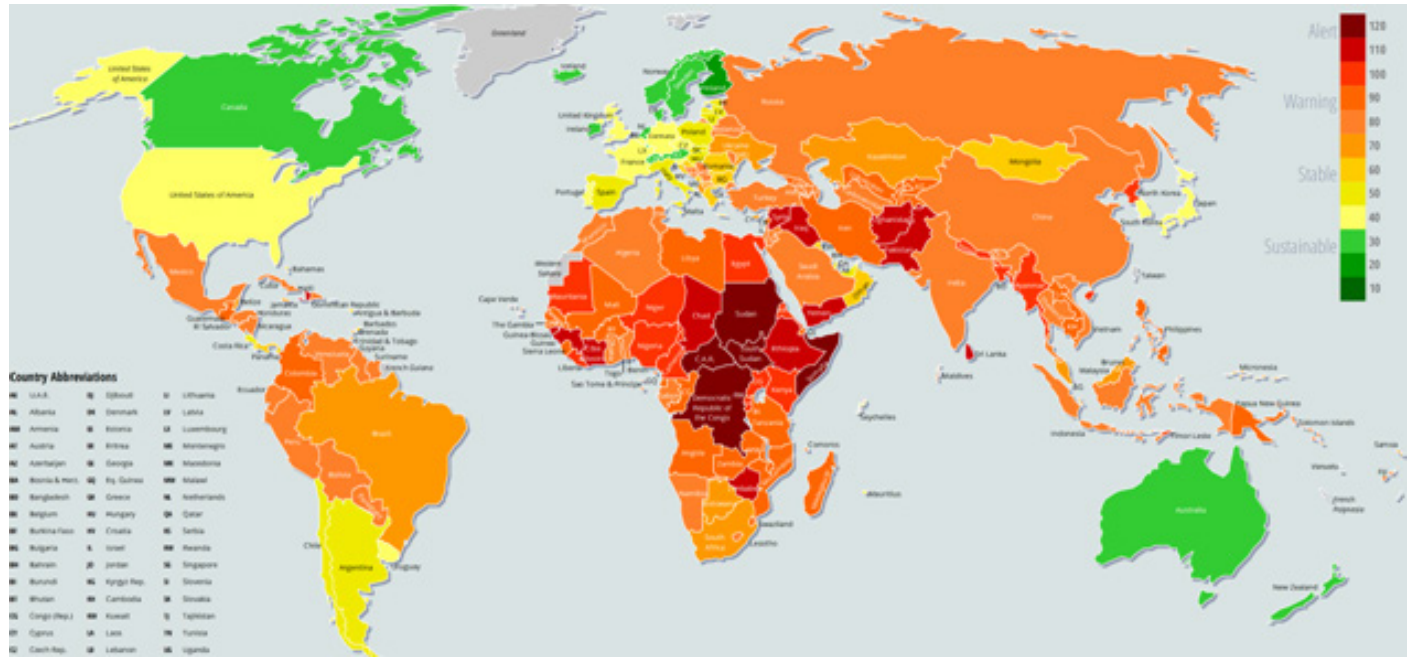

Map 1. Fragile States Index'. Source: Fund for Peace 2015b.

${ }^{1}$ Fund For Peace. 2015b. State Fragility Index. Available from: www.ffp.statesindex.org/rankings-2014 (accessed 13 January 2015).

In the EWP's map, countries in red have the highest risk of mass killing, which decreases through various shades of orange. High-risk countries cluster in Africa, the Middle East, and south Asia.

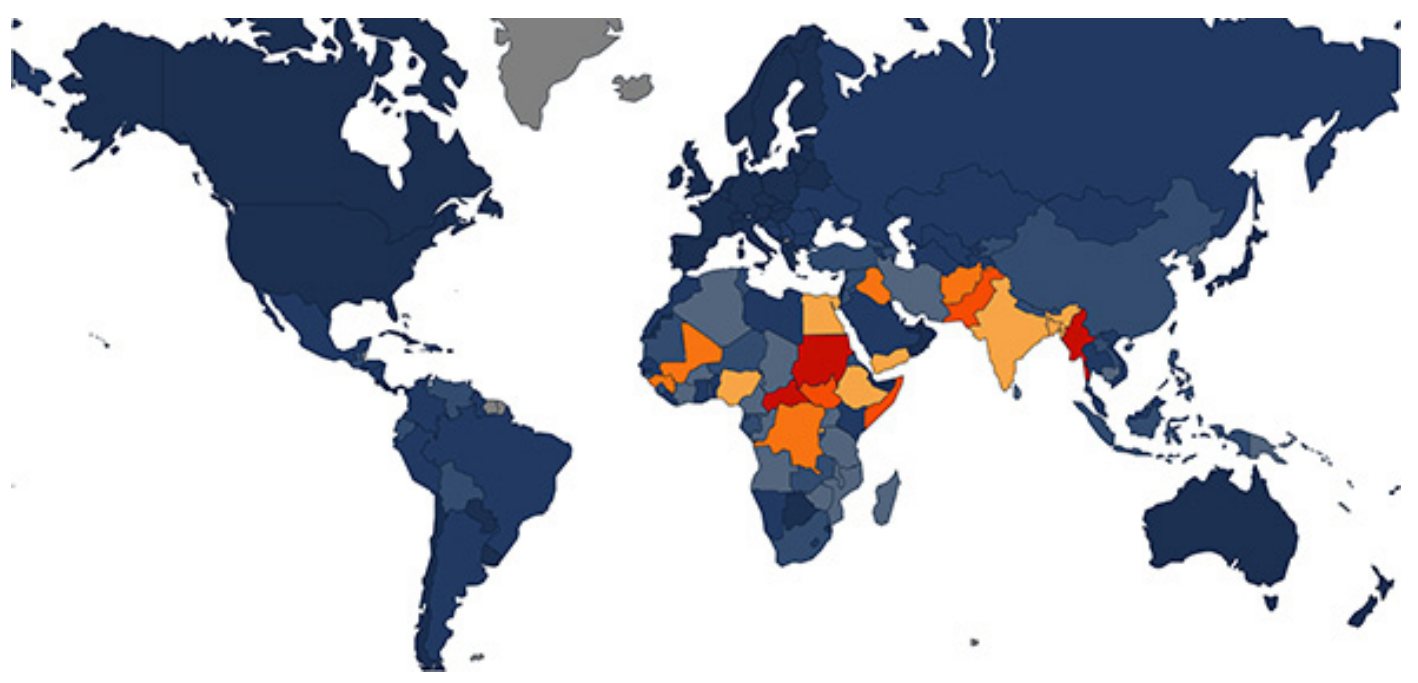

Map 2. EWP Model of State-Led Mass Killing'. Source: Early Warning Project 2015e.

${ }^{1}$ Early Warning Project. 2015e. “World Map.” Available from: http://www.earlywarningproject.com/map\# (accessed 9
June 2015).

Again, EWP's findings show a high concentration of ongoing and likely mass killing in the same regions as the Index's high-risk countries; nevertheless, because the various models do not systematically investigate regional or global factors, those clustering patterns are somewhat underexplored. ${ }^{25}$

\footnotetext{
${ }^{25}$ There is, for instance, a robust literature on civil war contagion effects across borders, and some on genocide and other forms of political violence. See Buhaug and Gleditsch 2008. Also see Harvey 2003; Escobar 2004 on global structural violence shaping national dynamics violence.
} 
Common Risk Indicators

What, then, are some of the main risk predictors for genocide and mass atrocity? They include several political, social and economic factors. Most of these will be unsurprising to scholars of genocide. Many qualitative comparative studies on the causes of genocide have had the same findings. Below I summarize these indicators in the risk assessment literature, though their specific articulation will differ across models.

1. A history of prior genocide or mass atrocities since the end of World War II consistently appears as important. Where there are prior histories, especially when the perpetrator group was not punished or removed from power, mass atrocities are somewhat more likely to occur.

2. Regime type is important. Genocide and mass atrocities are more likely in highly autocratic regimes than in democracies and somewhat more likely than in partially autocratic regimes (where non-competitive or partly competitive elections are possible, for instance). Governments that systematically limit or deny basic rights are unaccountable to their populations and respond to political contestation through force are much more likely to engage in genocide and related atrocities. The significance of regime type is also partly captured in some assessments by measuring the lack of executive constraints.

3. Ongoing state-led discrimination. As much of the genocide studies literature has long argued, patterns of increasing repression against already historically targeted groups, including the restriction of civil and political rights as well as violent coercion, precede genocide and mass atrocities. This is often tied to extremist elite ideology and/or prior devaluation of the targeted group, though various risk assessments specify this in different ways.

4. Political instability is also correlated with genocide and mass atrocity onset, with various models using different specifications of this (coup, civil war, assassinations, etc.).

5. Ongoing domestic armed conflict, such as civil war, is correlated with genocide and other atrocities. This is perhaps not surprising, given that war facilitates the logistics of mass killing and tends to radicalize ingroup and outgroup differentiations. ${ }^{26}$

6. Armed conflict in neighboring states can also radicalize domestic politics, serve as conduits for arms for insurgents, and raise elites' threat perceptions. ${ }^{27}$

7. Economic factors are somewhat more complex for forecasting. Harff has found that a low level of trade openness is an important predictor, but Butcher et. al. and Hazlett find that most economic factors are weak genocide predictors (including poverty and inequality levels), though some are better predictors of political instability and civil war, which in turn may lead to genocide and other atrocities..$^{28}$ This seems to indicate that the importance of economic factors depends on how they are mediated by political institutions, a point well known in the standard genocide studies literature. Rather than looking at country-level information (such as national rates of inequality like the Gini coefficient), it may be more useful to look at economic factors subnationally, by ethnic groups and other minorities, as has been done in civil war research. ${ }^{29}$

\section{Limitations and Caveats}

Statistical risk assessments have improved tremendously over the past decade and a half, as is illustrated by the examples above. They help provide a global snapshot of the regions of the world that are most likely to suffer from terrible violence, and to this extent can inform preventive policy by the United Nations and governments (provided, of course, the appropriate will to respond can

\footnotetext{
${ }^{26}$ Valentino, Benjamin, Paul Huth and Dylan Balch-Lindsay. 2004. “'Draining the Sea': Mass Killing and Guerrilla Warfare." International Organization Vol. 58, No. 2, 375-407.

${ }^{27}$ Butcher et al., "Understanding and Forecasting Political Instability."

${ }^{28}$ Stewart, Frances. 2013. "The Causes of Civil War and Genocide: A Comparison." In Responding to Genocide: The Politics of International Action. Edited by Adam Lupel and Ernesto Verdeja. Boulder, CO: Lynne Rienner, 47-84.

${ }^{29}$ Cederman, Lars-Erik, Nils Weidmann, Kristian Skrede Gleditsch. 2011. "Horizontal Inequalities and Ethnonationalist Civil War: A Global Comparison." American Political Science Review Vol. 105, No. 3, 478-495.
} 
be mobilized, which is often doubtful). However, there are several limitations and caveats that should be raised. I discuss some of these below.

Some risk assessments use a relatively narrow definition of genocide. Defining genocide in narrow terms produces comparatively few cases, a challenge for statistical analyses that require large numbers of observations for better forecasting. For these reasons, some scholars have preferred to focus on "mass killings," which as defined earlier yield comparatively many more cases for the purposes of analysis.

Related to this, a host of other forms of group destructive violence are often left out of assessment models. ${ }^{30}$ Sheri Rosenberg and Everita Silina have documented the ways in which genocide may occur by "attrition," such as the systematic denial of food and shelter or through forced relocations and enslavement that do not result in immediate death. ${ }^{31}$ The United Nations Genocide Convention also identifies a range of acts beyond direct killing that can qualify as genocidal, including causing seriously bodily or mental harm to the group, imposing measures intended to prevent births, and forcibly transferring children of one group to another. ${ }^{32}$ Naturally, these complex, long-term patterns of violence are much harder to model and measure than direct killing, but the result of excluding them may be to ignore countries that should otherwise appear high on watch lists. It is necessary to complement current risk assessments with regular, systematic assessments that take into account these other forms of violations. The Fragile States Index goes some distance in doing this by looking at a wide range of forms of violence and repression, but even here the emphasis is on measuring the relative resilience of the state.

Contemporary risk assessment models also tend to focus on very large-scale phenomena, and use baselines (say number of mass killings per year) for inclusion that can be rather high. A lower threshold and greater awareness of subnational patterns of violence, rather than just the country level, can provide not only a larger number of observations for analysis, but also greater sensitivity to cases where violence has yet to explode across the country.

Further improvements can be made to the data used in risk assessments, as Rost has argued. ${ }^{33}$ In some cases data may be missing or are unreliable for particular countries or regions (such as data on infant mortality rates), but often it is data for precisely those countries that are most prone to mass atrocities. Fatality estimates at the beginning of a violent episode can be especially unreliable due to undercounts, double-counts and manipulation. Similarly, there are limitations to using some off-the-shelf datasets, which have conceptualization and measurement problems. For example, the Polity dataset, used for measuring levels of democracy and thus regime type, has been criticized for having a host of conceptualization problems. ${ }^{34}$ And yet it is widely used in quantitative research on political violence.

Forecasting the onset of mass violence, whether genocide, mass atrocities, or related phenomena, always has to confront the challenge of balancing false positive and false negative predictions, which in turn have important implications for policy. A model should try to generate few false positives, or false alarms (that is, countries incorrectly forecasted to experience mass violence). Too many false alarms will not help analysts and policymakers in prioritizing their limited attention and resources. Reducing false alarms requires a high level of certainty about the likelihood of violence in particular countries during the given forecasting period, and this normally results in generating watch lists that include relatively obvious high-risk countries. However, reducing false positives may also mean a commensurate rise in the number of false negatives (i.e., those countries

\footnotetext{
${ }^{30}$ Birger Heldt's definition of atrocities "excludes indirect deaths caused by disease, starvation and crossfire" and "other indirect methods." See Heldt, "Mass Atrocities Early Warning Systems," 13.

${ }^{31}$ Rosenberg, Sheri P. and Everita Silina. 2013. “Genocide by Attrition: Silent and Efficient.” In Genocide Matters: Ongoing Issues and Emerging Perspectives. Edited by Joyce Apsel and Ernesto Verdeja. New York: Routledge, 106-126; Farmer, Paul. 2004. "An Anthropology of Structural Violence." Current Anthropology Vol. 45, 305-325.

${ }^{32}$ United Nations General Assembly. 1948. Convention on the Prevention and Punishment of the Crime of Genocide. Available from: www.treaties.un.org/doc/Publication/UNTS/Volume\%2078/volume-78-I-1021-English.pdf (accessed 3 January 2015).

${ }^{33}$ Rost, “Will It Happen Again?" 42, 59.

${ }^{34}$ Goertz, Gary. 2005. Social Science Concepts: A User's Guide. Princeton, NJ: Princeton University Press.
} 
that were not predicted to experience mass violence during a given period but did experience it). So, to the extent that a model is trying to lower the number of false negatives, it risks raising the number of false positives, and vice versa. This is a constitutive tradeoff in forecasting, though it should be noted that actual future cases of mass violence (future true positives) are often today's false positives.

Finally, and more generally, there is a danger that decision makers ascribe too much certainty to these probabilistic predictions, which can in turn shape policy choices. Part of this is an epistemological issue-how certain can we be of the predictions? The works discussed above are admirably clear about their scope of applicability and limitations. In speaking about genocide, Rost notes that, "for any model, picking out events that are so rare that they only occur in less than one percent of the cases included is difficult". ${ }^{35}$ However, the growing tendency in policy circles to treat "big data" quantitative research as categorically superior to other forms of research risks producing a misplaced sense of forecasting accuracy for mass violence and instability. The kind of scientism and big data hubris that have pervaded policy planning may generate a fictitious sense of foreknowledge and sidelines case experts who may make crucial analytical contributions.

\section{Early Warning}

There is no hard line between risk assessment and early warning, but as discussed earlier, early warning models tend to focus on short- and midterm predictions. Rather than analyzing broad structural conditions that point toward risk of some future instability or violence, early warnings include dynamic factors and are meant to be sensitive to changes in political context that may trigger violence. In general, countries that are deemed high-risk become the focus of early warning monitoring, so that risk level serves as a condition for early warning selection. As is the case with risk assessments, early warning models are often predicting somewhat different events-genocide, civil war, mass killing, mass atrocities, and the like-and thus may employ a variety of factors.

Policymakers often emphasize that what they need is better early warning. ${ }^{36}$ Although risk assessments are naturally valuable, accurate and timely knowledge is especially important for short term preventing responses. And yet, producing reliable early warnings is extremely difficult. Even for high-risk countries, predicting with any degree of accuracy when violence may eruptespecially atrocities such as mass killing and genocide - can be especially vexing.

An important point of contention for early warning modeling concerns the relative strengths of various methodological approaches. Should one rely on quantitative (statistical) approaches, qualitative evaluations that use systematic case study comparisons, or expert-based assessments of single cases? Some scholars, such as Barbara Harff, have argued that quantitative models hold significantly more promise than the alternatives because they are open to testing and falsification.

"Early warning efforts should be done in a systematic fashion using theoretically tested models-quantitative analysis - not just untested theory or experts' insights... The social sciences cannot afford to depend on insiders' knowledge or hunches and then cry "wolf" when there is no solid evidence that we are facing a genocide rather than some other violent event" ${ }^{37}$

The Fund for Peace advocates a combination of quantitative and qualitative approaches, but also remains skeptical of privileging specialized expert knowledge:

“To have meaningful early warning, and effective policy responses, assessments must go beyond specialized area knowledge, narrative case studies and anecdotal evidence to identify and grasp broad social trends. An interdisciplinary combination of qualitative research and quantitative methodologies is needed to establish patterns and acquire predictive value". ${ }^{38}$

\footnotetext{
${ }^{35}$ Rost, “Will It Happen Again?,” 42.

${ }^{36}$ Albright and Cohen. Preventing Genocide.

${ }^{37}$ Many researchers who make this point cite the work of Philip Tetlock, who argues that expert judgment is not especially reliable in trying to predict trends in international politics. See Tetlock, Philip E. 2006. Expert Political Judgment: How Good Is It? How Can We Know? Princeton, NJ: Princeton University Press; Harff, "Detection: The History and Politics of Early Warning," 101.

${ }^{38}$ Haken et al., Failed State Index 2014, 9.
} 
Other scholars have argued, however, that early warning prediction requires extensive expert knowledge. This is so, the argument goes, because experts have a more sophisticated understanding of the motives and goals of various political actors and they know the political and historical context of the conflict. Quantitative studies reduce the complexity of conflict and risk missing important dynamics and events that can trigger violence, or at best provide only information that is too generalized to be policy-relevant in the short- and midterm. ${ }^{39}$

The question of whether of whether quantitative, qualitative or expert-based approaches are superior remains unresolved, though most EW tends to be highly qualitative and dependent on expert interpretation (indeed, there are few early warning models in current use that are wholly or primarily quantitative). Nevertheless, this debate appears rather artificial. Given the difficulty of predicting complex violent events in the short- or midterm, it seems reasonable that a combination of statistical and qualitative approaches, as well as expert judgments, should be employed. Statistical models provide important insights into general patterns of violence onset and escalation through analyses of large numbers of similar cases, and they help identify what factors are the most important to monitor. However, qualitative assessments are necessary to develop causal models (rather than only correlative, typical of statistical approaches) that can assist in identifying patterns and triggers of violence escalation and restraint. Case experts are needed to interpret whether certain events may constitute violence accelerators and how events may impact the actions of other actors, given the specific case context. They can also assist in interpreting particular kinds of information that are not amenable to easy quantification, such as how ethnic or religious identities function in certain locations and how they may become politicized. The strongest EW approaches will likely be those that combine quantitative, qualitative and expert analyses. However, as Harff points out, quantitative early warning models are still not well developed.

A host of early warning models exist, many of them developed by nongovernmental organizations, governments, and international institutions such as the United Nations, often in conjunction with scholars in academia. ${ }^{40}$ Many of these groups publish outlines of the EW models they employ, but unfortunately few of them publish specific material on methodology, such as how their information is gathered, how sources are evaluated, and how the factors and variables in their various early warning models are operationalized (that is, how evidence is interpreted in light of the models). Unfortunately, without further elaboration of how information is interpreted it is difficult to evaluate the efficacy of various early warning models, which means that the discussion below is somewhat briefer than that of risk assessments. Nevertheless, even though methodological issues are rarely addressed at length in EW analysis, the violence triggers across models appear to be relatively similar. Below I first canvass organizations that produce early warning reports and then present the most common early warning triggers.

The United Nations has been involved in early warning for a number of decades, though until relatively recently it had not systematically coordinated the collection of information across its many agencies. Information gathering for early warning already occurs in country-based and global offices across the UN, including in the UN Development Programme, the Department of Peace Keeping Operations, the Department of Political Affairs, the Office for the High Commissioner for Refugees, the Office for the Coordination of Humanitarian Affairs, the World Food Programme, and most recently the big data collection project called Global Pulse (previously the Global Impact and Vulnerability Alert System). Each of these offices collects information to assist its own particular

\footnotetext{
${ }^{39}$ Hamburg, David A. 2010. Preventing Genocide: Practical Steps Toward Early Detection and Effective Action. Boulder, CO: Paradigm Publishers; Stewart, Rory and Gerald Knaus. 2012. Can Intervention Work? New York: W.W. Norton.

${ }^{40}$ Space limitations preclude discussing many other important early warning initiatives. See the work of the Genocide Prevention Advisory Network available from: www.gpanet.org (accessed 5 June 2015); the United States Holocaust Memorial Museum's Center for the Prevention of Genocide available from: www.ushmm.org/confront-genocide (accessed 5 June 2015); International Alert available from: www.international-alert.org (accessed 5 June 2015); Satellite Sentinel Project available from: www.satsentinel.org (accessed 5 June 2015); and the Forum for Early Warning and Early Response available from: www.fewer-international.org (accessed 5 June 2015). The FAST early warning unit at Swisspeace Foundation is no longer operating, but it did produce important work, discussed in Krummenacher and Schmeidl 2001. US military efforts like the Integrated Crisis Early Warning System (ICEWS) are discussed in O'Brien, Sean. 2010. “Crisis Early Warning and Decision Support" International Studies Review Vol. 12, 87-104.
} 
mandate, but until the advent of a special UN office dedicated to genocide prevention there was no systematic analysis of information relevant to mass atrocity prevention and detection. ${ }^{41}$

The UN Office of the Special Adviser on the Prevention of Genocide was established by the Security Council in 2004. In 2010, the office was expanded to include the promotion of the 'responsibility to protect' principle among UN member states, and it is now called the Office on Genocide Prevention and the Responsibility to Protect (OGPRP). The mandate of the special adviser includes collecting existing information from the numerous branches of the UN system, acting as a "mechanism of early warning to the UN Secretary-General," making recommendations to the UN Security Council on preventing and stopping genocide, and liaising within the UN system to strengthen prevention, detection and analysis efforts. ${ }^{42}$ The OGPRP recently extended its focus to "mass atrocity crimes," which include genocide, war crimes, crimes against humanity and ethnic cleansing. ${ }^{43}$ It currently uses a "framework of analysis" for mass atrocity crimes employing fourteen risk factors that together produce an overall early warning evaluation. The framework relies on the qualitative analysis of information from various UN bodies as well as NGO, news and scholarly sources.

In its early days, the office was severely understaffed and under-resourced and did not seem to have much of an impact on policy or advocacy work. ${ }^{44}$ In recent years its staff has grown and become more professional, and its work is analytically more sophisticated. It produces regular public reports and advises the Secretary-General and Security Council, though given the sensitivity of its sources most of its reporting is confidential with limited circulation at the UN. Nevertheless, the OGPRP has emerged as an important player in the early warning field.

A number of regional organizations engage in early warning monitoring as well. These include the Organization for Security and Cooperation in Europe, the European Union's Policy and Planning Unit in the European Council, the Continental Early Warning System in the African Union, The Economic Community of West African States' ECOWARN Office, and the Department of Sustainable Democracy and Special Missions in the Organization of American States. ${ }^{45}$ These organizations secure information from a variety of sources, some confidential, and produce regular internal analyses for policy advice and occasional public reports for broader distribution. Most of them do not release detailed information on their early warning models. ${ }^{46}$

In 2011, US President Barack Obama ordered the creation of the Atrocities Prevention Board (APB) to coordinate an inclusive government approach to risk assessment and early warning. ${ }^{47}$ The APB was established the following year and includes regular monthly meetings of high-level

\footnotetext{
${ }^{41}$ Zenko, Micah and Rebecca R. Friedman. 2011. “UN Early Earning For Preventing Conflict,” International Peacekeeping Vol. 18, No. 1, 21-37.

${ }^{42}$ United Nations Security Council. 2001. Resolution S/Res/1366. Available from: www.responsibilitytoprotect.org/files/ SC Resolution1366 31Aug2001.pdf (accessed January 6, 2015).

${ }^{43}$ United Nations Security Council. 2001. Resolution S/Res/1366. Available from: www.responsibilitytoprotect.org/files/ SC Resolution1366 31Aug2001.pdf (accessed January 6, 2015).

${ }^{44}$ Hehir, Aidan. 2010. "An Analysis of Perspectives on the Office of the Special Adviser on the Prevention of Genocide" Genocide Studies and Prevention Vol. 5, No. 3, 258-276.

${ }^{45}$ See the Organization for Security and Cooperation in Europe, Early Warning and Early Action available from: www. osce.org/secretariat/107485 (accessed 15 January 2015); European Union Policy and Planning Unit, The Early Warning and Conflict Prevention Capability of the Council of the European Union available from: www.ifp-ew.eu/pdf/0611prelisbon.pdf (accessed 15 January 2015); African Union, Continental Early Warning System available from www.peaceau.org/uploads/ early-warning-system-1.pdf (accessed 15 January 2015); Economic Community of West African States, ECOWARN available from: www.ecowarn.org (accessed 26 March 2015); Organization of American States, Department of Sustainable Democracy and Special Missions, available from: www.oas.org/en/spa/dsdsm/ (accessed 15 January 2015). A useful overview is found in Wulf, Herbert and Tobias Debiel 2009. "Conflict Early Warning and Response Mechanisms: Tools for Enhancing the Effectiveness of Regional Organizations? A Comparative Study of the AU, ECOWAS, IGAD, ASEAN/ARF and PIF." London: Crisis States Research Centre.

${ }^{46}$ Military and intelligence organizations also produce early warning analyses, but little detailed information is available on these efforts. See Albright and Cohen, 24-25; Kriendler, John. 2006. "NATO Intelligence and Early Warning." Conflict Studies Research Centre at the Defence Academy of the United Kingdom, Vol. 06, No. 13: pages 1-10; Hamburg, Preventing Genocide, 256-264.

${ }^{47}$ White House. 2011. Presidential Study Directive on Mass Atrocities PSD-10. Available from: https://www.whitehouse. gov/the-press-office/2011/08/04/presidential-study-directive-mass-atrocities (accessed December 20, 2015).
} 
Verdeja

officials from various governmental agencies to share information, identify atrocity risks and develop coherent policy responses. ${ }^{48}$ The APB focuses on potential or ongoing high-risk cases that may otherwise be missed, rather than major cases such as Syria already receiving significant attention. ${ }^{49}$ Little is known of the APB's effectiveness, however; its meetings and findings are confidential and it has not reached out in any sustained fashion to human rights NGOs or the broader human rights scholarly community. Its risk assessment and early warning models are not available (though they are reportedly based on Harff 2003 with some adjustments and extensive qualitative analysis). ${ }^{50}$ Sarah Sewall, Under Secretary for Civilian Security, Democracy and Human Rights at the State Department sits on the APB and has stated that the Board "sounded the alarm" on Burundi in 2015, Islamic State attacks on the Yazidi in 2014, and the Central African Republic in $2013 .{ }^{51}$ However, the lack of information on the ABP's work, including the kind of RA/EW models it employs, makes it very difficult to evaluate the Board's overall impact.

The nongovernmental organization Genocide Watch, founded and run by noted genocide scholar Gregory Stanton, employs a ten-stage model of analysis (updated from eight stages). The ten stages range from "classification" of groups into exclusive categories through "extermination" and finally "denial." The stages are "predictable but not inexorable," nor are they linear..$^{52}$ The model is based on the scholarly literature and is especially helpful for case study work. Genocide Watch releases a regular list of countries at high risk and also sends out early warning alerts when "politicide or genocide is imminent" and declares "genocide emergencies" when genocide is underway. Although Genocide Watch uses the United Nations definition of genocide (which is notoriously narrow and problematic for policy purposes) ${ }_{1}^{53}$ in practice the organization covers a wide range of violent phenomena, closer to the more inclusive "mass atrocity crimes." 54

The International Crisis Group (ICG) monitors conflicts around the globe through a network of regional offices. The ICG produces the monthly report Crisis Watch on high-risk countries as well as occasional early warning "crisis alerts" on specific countries, the latter including but not limited to genocide and mass atrocities. It is among the best-known NGOs devoted to early warning and its large staff of area experts and field specialists mostly employ qualitative methods. ${ }^{55}$ The ICG consults regularly with policymakers and news media. Most of the cases it identifies appear on other risk watch lists and early warning lists, though the ICG does not publish its analytical framework or details of its methodology.

The Canadian Sentinel Project has regular early warning evaluations of a number of high-risk countries and regions around the world. Like many NGOs, the Sentinel Project uses traditional news media and expert interviews as sources, but it is particularly noteworthy for using new technologies in conjunction with partners on the ground to generate information for early warning analysis. The organization has used a risk profile based on Stanton's earlier "eight stages of genocide" to identify "situations of concern" (essentially high-risk cases), and then applies an early warning model to monitor those cases. Monitoring is done through the Conflict Tracking System (CTS), a data visualization program that tags events by relevant early warning indicators. It employs the popular Ushahidi crowdsourcing platform to process data from a variety of sources. ${ }^{56}$

\footnotetext{
${ }^{48}$ The APB is composed of 11 government agencies and is chaired by the National Security Council. There are also more frequent inter-agency meetings by lower-level staff.

${ }^{49}$ Norris and Malknecht, Atrocities Prevention Board.

${ }^{50}$ Private communication, State Department official. September 15, 2015.

${ }^{51}$ Sewall, Sarah. 2015. "Charting the US Atrocities Prevention Board's Progress." Available from: http://www.cfr.org/ human-rights/charting-us-atrocities-prevention-boards-progress/p36332 (accessed 22 December 2015).

${ }^{52}$ Genocide Watch. 2015a. "The 10 Stages of Genocide." Available from: www.genocidewatch.org/genocide/ tenstagesofgenocide.html (accessed 15 January 2015).

${ }^{53}$ Verdeja, Ernesto. 2013. “Genocide: Debating Definitions.” In Responding to Genocide: The Politics of International Action. Edited by Adam Lupel and Ernesto Verdeja, pages 21-46. Boulder, CO: Lynne Rienner.

${ }^{54}$ Genocide Watch. 2015b. "Countries at Risk" Available from: http://genocidewatch.net/alerts-2/new-alerts/ (accessed 15 January 2015).

${ }^{55}$ Communication from Isabelle Arradon, Deputy Chief Policy Officer and Director of Research, ICG. February 17, 2015.

${ }^{56}$ Sentinel Project. 2015a. Conflict Tracking System. Available from: https://thesentinelproject.org/2015/02/11/the-sentinelproject-launches-conflict-tracking-system/ (accessed 9 June 2015).
} 
The Sentinel Project focuses on a relatively small number of cases, and much of its current work is centered on local-level interventions rather than broad-based EW, but the CTS is very promising and should influence future early warning efforts. ${ }^{57}$

The Global Centre for the Responsibility to Protect (GCRP) is an NGO based in New York that promotes the strengthening of the responsibility to protect principle in the United Nations system. Among a variety of initiatives, it publishes a bimonthly report on "populations at risk" of mass atrocity crimes, with special emphasis on a select number of countries in Africa, the Middle East and Southeast Asia. Its early warning work is mostly focused on those countries and is largely directed at government and UN policymakers, news media and other human rights advocacy organizations. It is a particularly good source of material for specific countries.

\section{Common Early Warning Indicators}

These various organizations employ a wide range of early warning frameworks, but a close reading of their many reports reveals that the indicators they use tend to overlap. These indicators may apply to state forces, insurgent forces, or both, depending on the specific indicator. ${ }^{58}$ The most common ones include:

1. increased hate media, which may sanction the use of violence against already vulnerable civilian groups;

2. public rallies and popular mobilization against vulnerable groups;

3. upcoming elections, which may be perceived as threatening to ruling elites;

4. public commemorations of past crimes or contentious historical events that exacerbate tensions between groups;

5. rapid change in government leadership, such as through assassination or coup, which can create a power vacuum and result in violent contestation for political power;

6. natural disasters, which may overstretch already weak state capacity and embolden opposition groups;

7. sharp increase in repressive state practices, including removal of political, religious, civil and economic rights, stripping of citizenship; shift from selective to widespread patterns of repression;

8. arrest, torture, disappearance or killing of political, religious, or economic leaders;

9. physical segregation or separation of the targeted group from the broader population; forced removal or settlement of populations;

10. increase in weapons transfers to security forces or rebels;

11. rapid increase in opposition capacity, raising their perceived threat, or conversely a rapid decline in opposition capacity, which may serve as an opportunity to destroy them and their "civilian base";

12. deployment of security forces against previously targeted civilian groups;

13. commencement/resumption of armed conflict between government forces and rebels;

14. spillover of armed conflict from neighboring countries;

15. nowhere for targeted civilian groups to flee as violence escalates.

\section{Limitations and Caveats}

Much like risk assessments, early warning models have made impressive advances in the past decade and a half. The organizations discussed above today produce important analytical and advocacy work on potential crises around the world, and thanks to them decision makers are much better informed than in the past. However, early warning models do face some limitations. Below I identify a few of these.

The first concerns limitations in information. New information technologies including social media allow us to monitor crises essentially in "real time," so that older problems of limited data

\footnotetext{
${ }^{57}$ Sentinel Project. 2015b. Hakika. Available from: https://thesentinelproject.org/2014/02/17/how-it-works-una-hakika (accessed 9 June 2015).

${ }^{58}$ Fein, Helen. 2007. Human Wrongs and Wrongs (Boulder, CO: Paradigm Publishers, 2007), 134-135.
} 
are less pressing, though they are still a problem in some places (such as in northeastern Central African Republic during the spring 2013 phase of the civil war). Nevertheless, as Birger Heldt has argued, the surfeit of information raises challenges for verifying its accuracy and relevance; for instance, information may be unrepresentative (e.g., primarily from urban versus rural areas or elite versus non-elite sources), unverifiable, or willfully misrepresented..$^{59}$ Triangulating sources can address some of these concerns, but in rapidly changing political contexts this is often hard to do.

It can be especially difficult to interpret information during so-called complex emergencies, conditions that combine ongoing internal conflict with population displacements, existing food insecurity and "fragile or failing economic, political, and social institutions." ${ }^{60}$ It is exceptionally hard to know when violent tipping points are going to occur under such already precipitous conditions that have their own complex causes and vectors, which often may reinforce one another. ${ }^{61}$

In addition to these data and complexity problems, there is generally little information available on how early warning models are designed and used. As discussed earlier, many organizations that conduct early warning monitoring share relatively little about how they reach their conclusions, which makes it difficult to assess their strengths and limitations. Given the grave risks of false negative predictions, and to a lesser extent false positives, we need greater clarity on how violence triggers and accelerators are framed and evidence interpreted. This would allow comparisons across models, and thus advance our knowledge about which indicators and models work best. Greater transparency would also help illuminate how analyst biases shape interpretations of conflicts.

Early warnings must be "actionable"; that is, they must be analyses that decision makers can translate into concrete preventive policies. On this count, early warning models have been mixed. Some are particularly useful, such as the alerts by the International Crisis Group or the Global Centre for the Responsibility to Protect, but others can be vague and unhelpful for making sense of complex crisis events. There are of course limits to how actionable they can be, but we do not appear to be there yet.

A final point concerns unpredictability itself. As the UN notes in its own atrocity prediction work, "It can also happen that unpredictable events or circumstances aggravate conditions or spark a sudden deterioration in a situation, prompting the perpetration of atrocity crimes" ${ }^{62}$ Some events prove to be unpredictable triggers; there is simply a limit point to knowing how and when things will unfold, and this uncertainty counsels some caution about our abilities to predict events.

These are important limitations, but overall there have been marked improvements in early warning monitoring since the 1990s, and our knowledge today is well ahead of where it was twenty years ago. Further research should continue to pursue these successes and ensure that early warning analysis continues to be policy-relevant.

\section{Conclusion}

This article has canvassed contemporary risk assessment and early warning approaches in contemporary conflict prevention. Scholars, human rights groups, governments and international organizations have made impressive advances in identifying the main indicators of mass violence in its many forms for policy purposes. The article has also highlighted some areas for further development and advised realistic expectations about what degree of predictive accuracy we should expect. Of course, the ultimate challenge concerns whether political leaders will take these warnings seriously.

\footnotetext{
${ }^{59}$ Heldt, Birger. 2012. "Mass Atrocities Early Warning Systems: Data Gathering, Data Verification, and Other Challenges." Guiding Principles of the Emerging Architecture Aiming At the Prevention of Genocide, War Crimes, and Crimes Against Humanity. Available from: www.ssrn.com/abstract=2028534 or http://dx.doi.org/10.2139/ssrn.2028534 (accessed 23 January 2015). 22.

${ }^{60}$ World Health Organization. 2015. “Environmental Health in Emergencies.” Available from: www.who.int/environmental health emergencies/complex emergencies/en/ (accessed 14 January 2015).

${ }^{61}$ Heldt, Birger. 2013. "Genocide Intent and Randomness of Killings of Civilians." Available from: www.ssrn.com/2138171 (accessed 22 December 2014).

${ }^{62}$ United Nations Office on Genocide Prevention and the Responsibility to Protect, Framework for Analysis of Atrocity

Crimes, 17.
} 


\section{Acknowledgements}

Special thanks to Isabelle Arradon, Emmanuel Bombande, Anna de Courcy Wheeler, Benjamin Goldsmith, Gillian Kitley, Christopher Mauriello, Alessandra Necamp, Christopher Tuckwood and Stephenie Young for conversations on these issues and for answering my questions. Brittany Ebeling and Jennifer Flanagan provided valuable research assistance. An earlier version of this paper was presented at the Center for Holocaust and Genocide Studies at Salem State University.

\section{Bibliography}

African Union. 2015. Continental Early Warning System. Available from: http://www.peaceau.org/ uploads/early-warning-system-1.pdf (accessed 10 January 2015)

Albright, Madeleine K. and William S. Cohen. 2008. Preventing Genocide: A Blueprint for U.S. Policymakers. Washington, D.C.: United States Holocaust Memorial Museum.

Bellamy, Alex. 2009. The Responsibility to Protect. Cambridge: Polity.

Buhaug, Halvard and Kristian Skrede Gleditsch. 2008. "Contagion or Confusion? Why Conflicts Cluster in Space." International Studies Quarterly Vol. 52, No. 2: pages 215-233. http://dx.doi. org/10.1111/j.1468-2478.2008.00499.x

Butcher, Charles R., Benjamin E. Goldsmith, Dimitri Semenovich and Arcot Sowmya. 2013a. "Understanding and Forecasting Political Instability and Genocide for Early Warning." Sydney: Australian Government, Asia Pacific Centre for the Responsibility to Protect, The University of Sydney, The University of New South Wales. Available from: http:// www.sydney.edu.au/arts/research/atrocity forecasting/downloads/docs/Genocide PolicyReportGlobalLowRes final120905.pdf (accessed 7 January 2015).

Butcher, Charles R., Benjamin E. Goldsmith, Dimitri Semenovich and Arcot Sowmya. 2013b. "Forecasting the Onset of Genocide and Politicide: Annual Out-of-Sample Forecasts on a Global Dataset, 1988-2003." Journal of Peace Research Vol. 50, No. 4: pages 437-52. http://dx.doi.org/10.1177/0022343313484167

Cederman, Lars-Erik, Nils Weidmann, Kristian Skrede Gleditsch. 2011. "Horizontal Inequalities and Ethnonationalist Civil War: A Global Comparison." American Political Science Review Vol. 105, No. 3: pages 478-495. http://dx.doi.org/10.1017/S0003055411000207

Center for the Prevention of Genocide, United States Holocaust Memorial Museum. 2015. Available from: http://www.ushmm.org/confront-genocide (accessed 28 January 2015).

Clarke,John.2005. "Early WarningAnalysisforHumanitarianPreparednessand ConflictPrevention." Civil Wars Vol. 7, No. 1: pages 71-91. http://dx.doi.org/10.1080/13698280500074446

Early Warning Project. 2015a. Available from: http://www.earlywarningproject.com (accessed 9 June 2015).

Early Warning Project. 2015b. "Expert Opinion Pool." Available from: http://www. earlywarningproject.com/opinion pools (accessed 9 June 2015).

Early Warning Project. 2015c. "Wiki Survey." Available from: http://www.earlywarningproject. com/2015/01/12/relative-risks-of-state-led-mass-killing-onset-in-2015-results-from-a-wikisurvey (accessed 9 June 2015).

Early Warning Project. 2015d. "A New Statistical Approach to Assessing Risks of State-Led Mass Killing." Available from: http://www.earlywarningproject.com/2014/01/22/a-newstatistical-approach-to-assessing-risks-of-state-led-mass-killing (accessed 9 June 2015).

Early Warning Project. 2015e. "World Map." Available from: http://www.earlywarningproject. com/map\# (accessed 9 June 2015).

Economic Community of West African States. 2015. ECOWARN. Available from: http://www. ecowarn.org (accessed 26 March 2015)

Edwards, Paul N. 1997. The Closed World: Computers and the Politics of Discourse in Cold War America. Cambridge: MIT Press.

Escobar, Arturo. 2004. "Development, Violence and the New Imperial Order "Development Vol. 47: pages 15-21. http://dx.doi.org/10.1057/palgrave.development.1100014

European Union Policy and Planning Unit. 2010. The Early Warning and Conflict Prevention Capability of the Council of the European Union Available http://www.ifp-ew.eu/pdf/0611prelisbon.pdf (accessed 10 January 2015). 
Farmer, Paul. 2004. "An Anthropology of Structural Violence." Current Anthropology Vol. 45: pages 305-325. http://dx.doi.org/10.1086/382250

Fein, Helen. 2007. Human Wrongs and Wrongs. Boulder, CO: Paradigm Publishers.

Fortna, Virginia Page. 2008. "Does Peacekeeping Keep Peace? International Intervention and the Duration of Peace After Civil War." International Studies Quarterly Vol. 48: pages 269-292. http://dx.doi.org/10.1111/j.0020-8833.2004.00301.x

Forum for Early Warning and Early Response. 2015. Available from: http://www.fewer-international. org (accessed 5 February 2015).

Fund for Peace. 2015a. "Failed State Index - FAQ \& Methodology." Available from: http://www.ffp. statesindex.org/faq (accessed 14 January 2015).

Fund For Peace. 2015b. State Fragility Index. Available from: http://www.ffp.statesindex.org/ rankings-2014 (accessed 13 January 2015).

Genocide Prevention Advisory Network. 2015. Available from: http://www.gpanet.org (accessed 28 January 2015).

Genocide Watch. 2015a. "The 10 Stages of Genocide." Available from: http://www.genocidewatch. org/genocide/tenstagesofgenocide.html (accessed 15 January 2015).

Genocide Watch. 2015b. "Countries at Risk" Available from: http://genocidewatch.net/alerts-2/ new-alerts/ (accessed 15 January 2015).

Goertz, Gary. 2005. Social Science Concepts: A User's Guide. Princeton, NJ: Princeton University Press.

Goldstone, Jack, Robert H. Bates, David L. Epstein, Tedd Robert Gurr, Michael B. Lustick, Monty G. Marshall, Jay Ulfelder and Mark Woodward. 2010. "A Global Model for Forecasting Political Instability." American Journal of Political Science Vol. 54, No. 1: pages 190-208. http://dx.doi.org/10.1111/j.1540-5907.2009.00426.x

Haken, Nate, J. J. Messner, Krista Hendry, Patricia Taft, Kendall Lawrence, Laura Brisard, Felipe Umaña. 2014. Failed State Index 2014: The Book. Washington, D.C.: Fund for Peace.

Hamburg, David A. 2010. Preventing Genocide: Practical Steps Toward Early Detection and Effective Action Revised and Updated. Boulder, CO: Paradigm Publishers.

Harff, Barbara. 2003. "No Lessons Learned from the Holocaust? Assessing Risks of Genocide and Political Mass Murder since 1955." American Political Science Review Vol. 97, No.1: pages 57-73. http://dx.doi.org/10.1017/S0003055403000522

Harff, Barbara. 2013. "Detection: The History and Politics of Early Warning." In Responding to Genocide: The Politics of International Action. Edited by Adam Lupel and Ernesto Verdeja, pages 85-110. Boulder, CO: Lynne Rienner.

Harvey, David. 2003. The New Imperialism. Oxford: Oxford University Press.

Hazlett, Chad. 2011. "New Lessons Learned? Improving Genocide and Politicide Forecasting." United States Holocaust Memorial Museum. Available from: http://www.ushmm.org/m/ pdfs/20111102-hazlett-early- warning-lessons-learned.pdf (accessed 10 January 2015).

Hegre, Håvard and Nicholas Sambanis. 2006. "Sensitivity Analysis of Empirical Results on Civil War Onsets." Journal of Conflict Resolution Vol. 50, No. 4: pages 508-535. http://dx.doi.org/10.1177/0022002706289303

Hehir, Aidan. 2010. "An Analysis of Perspectives on the Office of the Special Adviser on the Prevention of Genocide" Genocide Studies and Prevention Vol. 5, No. 3: pages 258-276. http://dx.doi.org/10.3138/gsp.5.3.258

Heldt, Birger. 2009. "Risks, Early Warning and Management of Atrocities and Genocide: Lessons from Statistical Research." Politorbis Vol. 2, No. 47: pages 65-70.

Heldt, Birger. 2012. "Mass Atrocities Early Warning Systems: Data Gathering, Data Verification, and Other Challenges." Guiding Principles of the Emerging Architecture Aiming At the Prevention of Genocide, War Crimes, and Crimes Against Humanity: pages 13-32. Available from: http:// www.ssrn.com/abstract=2028534 (accessed 23 January 2015). http://dx.doi.org/10.2139/ $\underline{\text { ssrn.2028534 }}$

Heldt, Birger. 2013. "Genocide Intent and Randomness of Killings of Civilians." Available from: http://www.ssrn.com/2138171 (accessed 22 December 2014).

International Alert. Available from: http://www.international-alert.org (accessed 28 January 2015). 
Kriendler, John. 2006. "NATO Intelligence and Early Warning." Conflict Studies Research Centre at the Defence Academy of the United Kingdom, Vol. 06, No. 13: pages 1-10.

Krummenacher, Heinz and Susanne Schmeidl. 2001. Practical Challenges in Predicting Violent Conflict: FAST - An Example of a Comprehensive Early-Warning Methodology. Berne: Swisspeace Foundation.

Lupel, Adam and Ernesto Verdeja. 2013. "Developing the Political Will to Respond." In Responding to Genocide: The Politics of International Action. Edited by Adam Lupel and Ernesto Verdeja, pages 241-257. Boulder, CO: Lynne Rienner.

Matveeva, Anna. 2006. Early Warning and Early Response: Conceptual and Empirical Dilemmas. (Den Haag: European Centre of Conflict Prevention.

Melander, Erik. 2009. "Selected To Go Where Murderers Lurk? The Preventive Effect of Peacekeeping on Mass Killings of Civilians." Conflict Management and Peace Science Vol. 29, No. 4: pages 389-406. http://dx.doi.org/10.1177/0738894209106482

Meyer, Christoph O., Florian Otto, John Brante, Chiara de Franco. 2010. "Recasting the WarningResponse Problem: Persuasion and Preventive Policy." International Studies Review Vol. 12: pages 556-578. http://dx.doi.org/10.1111/j.1468-2486.2010.00960.x

Norris, John and Annie Malknecht. 2013. Atrocities Prevention Board: Background, Performance, and Option. Washington, D.C.: Center for American Progress.

O'Brien, Sean. 2010. "Crisis Early Warning and Decision Support" International Studies Review Vol. 12: pages 87-104. http://dx.doi.org/10.1111/j.1468-2486.2009.00914.x

Organization for Security and Cooperation in Europe. 2014. Early Warning and Early Action. Available from: http://www.osce.org/secretariat/107485 (accessed 15 January 2015)

Organization of American States, Department of Sustainable Democracy and Special Missions. 2015. Available from: http://www.oas.org/en/spa/dsdsm/ (accessed 10 January 2015).

Rosenberg, Sheri P. and Everita Silina. 2013. "Genocide by Attrition: Silent and Efficient." In Genocide Matters: Ongoing Issues and Emerging Perspectives. Edited by Joyce Apsel and Ernesto Verdeja, pages 106-126. New York: Routledge.

Rost, Nicolas. 2013. "Will It Happen Again? On the Possibility of Forecasting the Risk of Genocide." Journal of Genocide Research Vol. 15, No. 1: pages 41-67. http://dx.doi.org/10.1080/14623528 .2012 .759398

Satellite Sentinel Project. Available from: http://www.satsentinel.org (accessed 5 February 2015).

Schmeidal, Susanne. 2002. "Conflict Early Warning and Prevention: Toward a Coherent Terminology." In Early Warning and Conflict Management in the Horn of Africa. Edited by Ciru Mwaura and Susanne Schmeidal, pages 70-100. Lawrenceville, NJ: Red Sea Press.

Secretary General of the United Nations. 2006. Early Warning Systems: An Assessment of Capacities, Gaps and Opportunities Toward Building a Comprehensive Global Early Warning System for All Natural Hazards. New York: United Nations.

Sentinel Project. 2015a. Conflict Tracking System. Available from: https://thesentinelproject. org/2015/02/11/the-sentinel-project-launches-conflict-tracking-system/ (accessed 9 June 2015).

Sentinel Project. 2015b. Hakika. Available from: https://thesentinelproject.org/2014/02/17/how-itworks-una-hakika (accessed 9 June 2015).

Sewall, Sarah. 2015. "Charting the US Atrocities Prevention Board's Progress." Available from: http://www.cfr.org/human-rights/charting-us-atrocities-prevention-boards-progress/ p36332 (accessed 22 December 2015).

Shaw, Martin. 2013. Genocide and International Relations: Changing Patterns in the Transitions of the Late Modern World. Cambridge: Cambridge University Press. http://dx.doi.org/10.1017/ CBO9781139030694

Stewart, Frances. 2013. "The Causes of Civil War and Genocide: A Comparison." In Responding to Genocide: The Politics of International Action. Edited by Adam Lupel and Ernesto Verdeja, pages 47-84. Boulder, CO: Lynne Rienner.

Stewart, Rory and Gerald Knaus. 2012. Can Intervention Work? New York: W. W. Norton.

Tetlock, Philip E. 2006. Expert Political Judgment: How Good Is It? How Can We Know? Princeton, NJ: Princeton University Press. 
Ulfelder, Jay. 2013. "A Multimodel Ensemble to Forecast Onsets of State-sponsored Mass Killing." American Political Science Association Annual Meeting. Available from: http://www.ssrn. com/abstract=2303048 (accessed 10 January 2015).

United Nations General Assembly. 1948. Convention on the Prevention and Punishment of the Crime of Genocide. Available from: www.treaties.un.org/doc/Publication/UNTS/ Volume\%2078/volume-78-I-1021-English.pdf (accessed 3 January 2015).

United Nations Office on Genocide Prevention and the Responsibility to Protect. 2014. Framework for Analysis of Atrocity Crimes: A Tool for Prevention. New York: United Nations, 2014.

United Nations Security Council. 2001. Resolution S/Res/1366. Available from: www. responsibilitytoprotect.org/files/SC Resolution1366 31Aug2001.pdf (accessed 6 January 2015).

Valentino, Benjamin, Paul Huth and Dylan Balch-Lindsay. 2004. "'Draining the Sea': Mass Killing and Guerrilla Warfare." International Organization Vol. 58, No. 2: pages 375-407. http://dx.doi.org/10.1017/S0020818304582061

Verdeja, Ernesto. 2013. "Genocide: Debating Definitions." In Responding to Genocide: The Politics of International Action. Edited by Adam Lupel and Ernesto Verdeja, pages 21-46. Boulder, CO: Lynne Rienner.

Weiss, Thomas G. 2012. What's Wrong with the United Nations and How to Fix It. London: Polity.

White House. 2011. Presidential Study Directive on Mass Atrocities PSD-10. Available from: https:// www.whitehouse.gov/the-press-office/2011/08/04/presidential-study-directive-massatrocities (accessed December 20, 2015).

Woocher, Lawrence. 2011. "Is a Public Warning System Necessary?" United States Holocaust Memorial Museum. Available from: www.ushmm.org/m/pdfs/20111021-woocher-earlywarning.pdf (accessed December 23 2015).

World Health Organization. 2015. "Environmental Health in Emergencies." Available from: www. who.int/environmental health emergencies/complex emergencies/en/(accessed 14 January 2015).

Wulf, Herbert and Tobias Debiel 2009. "Conflict Early Warning and Response Mechanisms: Tools for Enhancing the Effectiveness of Regional Organizations? A Comparative Study of the AU, ECOWAS, IGAD, ASEAN/ARF and PIF." London: Crisis States Research Centre.

Zenko, Micah and Rebecca R. Friedman. 2011. "UN Early Earning For Preventing Conflict," International Peacekeeping Vol. 18, No. 1: pages 21-37. http://dx.doi.org/10.1080/13533312.2 $\underline{011.527504}$ 